\title{
The Changing Side of Art Education and A Restructuring Proposal for a New for Turkey Visual Arts Education
}

\author{
Nuray Mamur \\ Pamukkale University, Turkey \\ nmamur@pau.edu.tr
}

\begin{abstract}
Today, depending on the rapid advancement in technology and informatics, and the globalization, necessity for the increasing lifelong education requires change universities and various training programs. One of these programs, depending on the increase in the visual saturation, is undoubtedly the visual arts education, Today, in the context of the productions of contemporary art, changing aesthetic judgments, and social change, arts education, there is a need to rethink on the content of art education and art teacher education. Today's artists are no longer engaged in more and more social issues. They more prefer the use of technology in the context of thought to explain. Contemporary art, interdisciplinary approaches are preferred. All media graphics such as film, photography, illustration, interactive networking, and motion blended with each other. New art forms have emerged from these mixtures. The difference between low and high art has obscured. Therefore, art educator must be a close follower of these changes. In this context, this study is based on two aims. In this study primarily was addressed the effects of postmodernism on art and art education. The primary aim of this research is to discuss the effects of postmodernism on art and art education. The other aim is to provide new recommendations for a new constitution about visual arts teacher education in Turkey in terms of the experienced changes in art education.
\end{abstract}

Key words: Postmodernism, Postmodern art education, Contemporary art education, Visual arts teacher education 


\section{Introduction}

From 20th to 21 st century, it is seen that intellectual and semiotic characteristics of art productions has been giving shape to the structuring process of art education. For example, from the beginning of the 20th century to 1960 s, child and creativity centered approaches direct the art education. In the modernization period, which starts in 1900s, new materials are being used in art and this leads to new terms such as collage and assemblage. By the help of those terms, first step for modern art is taken. Since then, art education at school is interpreted as creativity based process that focuses on revealing the child's potential. In this approach, it is seen that children can express themselves without adult pressure. Also, unlike material support and stylistic approaches, art making process is foregrounded (Gaudelius \& Speirs, 2002). With the effect of modernism, between 1960s and 1990s, homogeneous elements of modern and postmodern art education have been systematized and Discipline Based Art Education becomes important (Eker, Baltaci \& Sengir, 2010). DBAE, which takes form according to artists, art historians, art critics, considers the child as a subject of the study (Gaudelius \& Speirs, 2002). This approach includes art history, art criticism, aesthetics, and art making. It plays an important role both in Turkey and in the world in shaping art education curriculum. However, it is insufficient in exploring understanding and discussing the social issues in contemporary art. In this context, after 1990s, a new movement begins in order to reconstruct art education. This approach focuses on visual culture and its education and it takes shape with postmodern theories and constructivist learning theory. This latest trend is known as contemporary art education or art and culture education in international literature. It focuses on critical thinking abilities by integrating contemporary art into the core of curriculum and visual literacy. In due course, this approach has been associated with surrounding visual culture as much as art practice. Fashion, advertising, cartoons, digital 
world are used so as to expand the scope of art education. It is attempted to construct transparent boundaries between art and daily life.

At this point, I focused on two questions in this study. First, as being members of visual arts departments in Turkey, how should we analyze the basics of art education that begins to gain acceptance and what should our attitude be towards these applications? Second, how can we make visual arts teacher education programs more functional and contemporary?

\section{Methodology}

In this study, I used an analytical method in the frame of descriptive survey method. In the

study, firstly, I resolved the expressions that push art education to change in international context. Then, I analyzed web pages of different universities to find out the effects of these expressions on art and art education programs. Finally, I expressed various recommendations in order for visual arts teacher education in Turkey to gain international quality.

\section{Findings}

\section{Topics reflecting on art education}

After the 1990s, it is seen that art education studies generally depends on visual culture, critical literacy, feminist theories, cultural studies, performance pedagogy, spectacle pedagogy, postmodernism and the use of information and communication technologies (i.e. Anderson, 2003; Duncum, 2001, 2002, 2008; Freedman, 1997, 2003; Garoian \& Gaudelius, 2008, Garoian, 2013; Keifer-Boyd, Amburgy \& Knight 2003; Musneckiene, 2012; Stokrocki, 2006; Sturken \& Cartwright, 2009, Tavin, 2000, 2002, 2003, 2004; Varto, 2012). In those art education studies, mostly the returns of globalization and inevitability of cultural change are emphasized by mentioning the rapid information flow. A new construction process is addressed by stating the outcomes of contemporary life, contemporary art productions and postmodern education theories. Efforts can be grouped under six titles in the light of 
literature, aim and content of the art education and teaching methods. These are; a) removing interdisciplinary boundaries/ multidisciplinary interactions, b) visual culture, c) changing meaning of aesthetics, d) visual literacy, e) experience with technology

a) Removing interdisciplinary boundaries/ multidisciplinary interactions: Depending on the technological developments, even geographical boundaries are becoming less important, the interaction between different subjects is inevitable. As a result, it is seen that new areas of knowledge and new forms are observed. According to Freedman (2003), interdisciplinary transitions are seen among purposes, forms and school subjects. In 1960s, everything was separated from each other by sharp boundaries and manifestos. In those years criticism towards modern era had created postmodernism and it had given rise to an environment in which everything was intertwined. In the field of art, collective movements, which are formed by modern period, gradually decreased and individuality and identity were more highlighted. Due to the effects of visual arts on mass media and modern life, the boundaries between art and daily life have been deleted. As a result, it is observed that the distinction between elite and popular culture has collapsed (Sarup, 1997, cited in Eker \& Seylan, 2005). Since 1965, instead of dealing with style and aesthetic, a number of artists have developed ideas and theories on the definition and purpose of art, the role of artist and the viewer, so as to enlarge the borders of art and reshape the art object's status (Yilmaz, 2010). In addition to the formal development of art, they have chosen the way of questioning work of art, museums, art environment, and the relationship between art and life. As a result they have succeeded in expanding the boundaries of art. Since 1980s, thanks to the effects of conceptual art, artists have developed the idea that any theory and view can be considered as art. This process has increased the interaction of art disciplines with philosophy, literature, psychology, sociology and history and popularized the interdisciplinary understanding (Yilmaz, 2010, p.186). 
By forcing the interdisciplinary boundaries, the diversity of formal norms and methods has increased. Formal quests have resulted in moving, variable and instant technological formulations. After removing the internal borders of art, it is necessary to expand the goals of art education. It has been a must for fine arts focused art education contents to include political, economic and technological dimensions. At this stage of art education, efforts on developing new methodologies that focus on understanding and interpreting the richness of visual experiences in contemporary culture has begun. Advertisements, toys, posters, computer networks, children's books are used in order to expand the subject area of art education. Thus, a connection between many visual culture formulas and daily life has been made.

b) Visual culture: In 1990s, visual culture was not only used in art education based researches, but it also became the subject of art history, culture, communication and all kinds of media oriented studies. This is because all of human experience is over visual images more than ever (Mirzoeff, 1999) or as Freedman's (2003) says, contemporary culture is visual. Visual culture does not limit itself with art; it accepts all man made visuality as the main ingredient of its content. Furthermore, he emphasizes that this acceptance should be understood as an obligation not arbitrariness (Soganci, 2011). In this context, the content of art education can expand via visual culture. This issue is regarded as an issue that will connect art education to daily life.

c) Changing meaning of aesthetics: In the end of 19th century, industrialization, developing technology, and the emergence of modernity via and scientific movements had resulted in a formalist aesthetic in art pavement. Formalist aesthetics focused on analyzing the art items that reflect the perceptual and physical characteristics of art work such as design elements (line, shape, color) and design principles (rhythm, balance and unity) (Freedman, 2003). The content of a work of art that activates feelings, its beauty and the harmony in it created the 
definition of aesthetic. However, at the end of 20th century, the importance of beauty and the harmony in a work had lost their importance. the diversity of art cases and applications has changed the meaning of aesthetics. contemporary art exhibits a tendency in focusing on the meanings and symbols that are configured by viewers instead of artists self-expression. Efland (1996) in his study, Postmodern Art Education: An Approach to Curriculum, states that modernism is credited in terms of harmony and beauty and he also mentions that postmodernism is established so as to focusing on culture studies to draw attention to the observed issues in the future (cited in Aykut, 2012). In this context, it is necessary to pay attention to the creation of an art work, its meaning and the intention of the creator instead of the work of art itself. In postmodern art education content, Efland (1996) thinks art as a cultural production and explains art as creating the symbols of reality whose focus and aim are shared. Also he states thanks to art it is possible to understand social and cultural environment deeply (cited in Aykut, 2012).

d) Social context: In art education researches, social content is discussed in three different contexts. Firstly, it can be said that contemporary artists have a tendency towards the effects of cultural products on daily life. In those products reality and fiction are intertwined. Especially contemporary artists deal with the social rules that determine the system by owning and transforming them, they create meaning from familiar images that helps them to open the doors of inquiry (Antmen, 2010). Secondly, similar to contemporary artists art teachers don't want to stay indifferent to new forms of life that are formed by popular culture products. They take the responsibility of developing educational methods that helps to question every message emitted from the bombardment of images due to the spread of mass media.

The third aspect that connects social content to art education is constructivist learning method. According to Musnekiene (2012), who advocates that knowledge is structured through social interactions, this approach is appropriate for the contemporary content of art education. 
According to Gaudelius and Speirs (2002) social content in art education serves to two different levels. Firstly and most importantly, it may help to understand more general categories such as poverty and violence. Secondly, it helps to discover more specific topics such as gender, race, religion, discrimination. Social issues all over the world directly or indirectly affect the individual. Therefore, in order to live in a more reliable and democratic society, children should learn how to react social issues and interact with others. The purpose is to develop children's critical way of thinking so as to help them fulfill their functions as a member of the society.

d) Visual literacy: One of the concepts that generate contemporary art education is critical literacy, which arises from the interaction with critical pedagogy. Critical pedagogy was revealed by Fereire as well as Gramsci, Marcuse, the Frankfurt School of Critical Theory, Giroux, McLaren and thinkers such as Apple (Gaudelius \& Speirs, 2002).

Critical pedagogy pursuits the knowledge that helps students understand the "social function" of a particular form of knowledge (Mc Laren, 2003, p.71). According to Giroux (2000) critical pedagogy depends on student's life his/her problems and needs. Taylor (2000) states that critical pedagogy activates students' imaginations, desires and intellectual structure and encourage them question social, political and economic forces that affect their lives. in this sense, it constitutes the basic philosophy of methods that are about discovering visual images which are seen everywhere and every moment (Duncum, 2002, 2008; Freedman, 2003; Tavin, 2000, 2004).

e) Experience with technology: Development of technological skills and knowledge in art education includes both contemporary art practices that use computers and media technology and the opportunities brought by technology. Contemporary artists have known to internalize technology via a critical approach and to use it effectively (Beyhan, 2011). Technology has affected the field of visual arts in terms of innovations in art production, viewing conditions, 
and materials that are used. Unlike traditional media, new media formats present alternatives such as copying, designing, playing and deleting (Freedman, 2003, Musneckiene, 2012, Tillander, 2011). Technology supports visual thinking in terms of rapid production and cognitive ability.

Another dimension of technological experience can be accepted as offered opportunities in education. Freedman (2003) mentions that children can't remain indifferent to media forms. Especially in our era, when we consider the time that young people and children spend on personal websites, web blogs, video stores; this new world must be transformed into a valuable source for education. In this context, art educators have been developing new projects to use virtual world for the benefit of art education. For example, software known as Second Life is being used for intercultural dialogue (Keifer-Boyd, 2009, 2010; Tillander, 2011). Today, intercultural dialogue is one of the main art learning areas of European Union. Therefore, the effective use of technology is highlighted in order to support cultural identity and intercultural dialogue. It is a fact that after 1990s technology has reduced the importance of geographical distance. For this reason, it can be said that inter-communal interaction is inevitable.

Another element highlighted on the technological experience in the digital world consumption patterns and merchandising platforms is the necessity in developing experiences on topics such as web site, e-portfolio and blogging. New modes of production, raises new environments that meet with the audiences (Beyhan, 2011) and as a result the discovery of these environments is a requirement.

\section{Changes Reflected in the Art Department of Education Environments}

Art is an open concept and it always evolves changes. Similarly, art education continues to change by collaborating with new art practices (Gude, 2007). After 1990s art education 
researches have put into practice in two perspectives. These are structuring the art program and updating the content of teaching.

a) Structuring art programs: Advances in the contemporary world, interdisciplinary transitions and new point of view presented by postmodernity have caused universities to change their classification of art programs. For example, when teacher training collages and art departments of the universities are analyzed, it can be seen that there is no sharp boundaries between painting, sculpture, ceramics, printmaking and graphic design programs. Furthermore, depending on the social and technological changes in art practices, new programs in art practices can be seen which allow the integration of interdisciplinary studies. For example when we examine the programs of Pennsylvania, Ohio, Arizona State University, it can be seen that theory is put into practice. In Penn State University School of Visual Arts and Interdisciplinary Digital Design, Art, Art Education and Art Education Certificate Program creates by degrees (Bachelor of Science (in Art Education), Bachelor of Design (in Interdisciplinary Digital Studio), Bachelor of Arts (in Art) Post Baccalaureate at Certification) in each will allow you to switch between programs has identified common course. When programs related lessons were analyzed, the development in art idea (Ideas as Object, Ideas as Visual Images) visual culture pedagogy (Visual Culture and Art Education, Diversity, Pedagogy, and Visual Culture, Visual Culture and Educational Technologies) and technological experiences (New Media: The art of Web Design, Intro to Digital Arts) promoting courses are outstanding. In art education department of Ohio State University, Digital Art, Digital Art Education, Visual Culture in Education Multiculturalism has taken place in the program's courses.

b) Updating the content of teaching: From the beginning of $1990 \mathrm{~s}$, socio-cultural content has been added to the modernist curriculums. Haynes (1995) draws attention to three elements about the changes in contents (cited in Clark, 1996). 
1) Developing awareness in students' present cultural value systems,

2) Expands value systems through being exposed to alternative world views,

3) Challenging students to actively create a more equal future (p. 83)

According to Gude (2004) three factors should evolve in structuring art programs. These are: a) curriculum based on generative themes that relate to the lives of students and their communities, b) studio art projects based on diverse practices of contemporary art making and related traditional arts and c) art as investigation understanding the art of others and seeing their own art making, not as exercise, but as research that produces new visual and conceptual insights (p. 6). In the United States, the striking elements in each of these statements are current life and social content, practices of looking and student's self-awareness development. Similarly, there are similar structures in European art education.

It is possible to see in a report involving 30 European art education programs prepared by Eurydice network that art education programs not only focus on developing artistic skills but also developing critical thinking, learning cultural heritage and its diversity and developing self-expression skills. In the same report, close cooperation with the art world and with the ICT (Information Communication Technology) use is indicated on the necessity of developing projects.

\section{Conclusion}

Although education is a concept that gains its basic references from culture, it also includes some universal dimensions. In the world, the effects of globalization and postmodernism on art force and art education programs to change. In Turkey, in order to prepare art teachers for the global societies of future and to gain an international perspective in art teacher education, it is inevitable to start seeking a new model. In this planning two elements mentioned in Dewey's (2005) book "Art as Experience" can be used as a flashlight. First one is this 
Anadolu Journal of Educational Sciences International, Art Education Special Issue, November 2015

statement: "If we educate today's children with yesterday's methods, we stole from their futures". Second one is as follows: "We should be flexible in allowing the freedom of individual experiences and we should be strict in the awareness of shaping the individual strength in our programs". Flexibility requires being welcoming towards change. For this reason it is necessary to form a program evaluation system. What is important here is being able to do a synthesis between global tendencies and the country's condition. As educators in Turkey, What can we do to achieve international standards in art education? What is the starting point? It is inevitable to start seeking a new model.

1) To be united under a national association that will support art and culture education: As art educators, art students, art teachers and art education scholars we can unite under a single association so as to be more effective in national art education curriculum. Thus, we can determine a national art education policy, and have a voice in school programs of Ministry of Education and course hours. Art Education Symposiums can be a tradition by holding them every year in a different university. Moreover, we can discuss the problems of art education on an academic ground and we can share new discoveries in a refereed journal. Also teachers can share their creative practices in a journal or magazine designed for them.

2) Restructuring under fine arts faculties: Teacher training in fine arts should be structured as a program of fine arts faculties. Thus, as art educators, we can pursue contemporary art practices and develop new techniques in the field of contemporary art production teaching methods and techniques. Furthermore, we cannot say that the increasing number of the fine arts education programs is fulfilling the requirements of contemporary art education. In this sense, art education programs can be designed as a program under the title of fine arts faculties. This will help in using the country's resources more effectively. 
3) Rescheduling teacher education in visual arts: We can bring new approaches to the programs of visual arts teachers in order to capture change in art and society. Since there are no boundaries between disciplines today, we can ponder over restructuring main art and elective art courses. Each course is in an equal position for an art teacher so we can offer best opportunities for the further development of a teacher candidate.

We can think on new attitudes, approaches and definitions that will help art courses gain modern qualifications. We should focus on new teaching methods via dialogues. By the help of dialogues, students' intellectual abilities will develop and they will learn evaluating an issue from different sides.

We should create courses that will allow using ICT in the field of art and teacher education. We should encourage students to experience designing websites about the consumption patterns and exhibition platforms, preparing electronic portfolios and blogs.

4) Helping students discover themselves and the society: Daily life and social issues should be included in the art education course content. In courses, we should discuss important social topics. For example, environmental problems, rapid urbanization, gender discrimination, violence, women's killings, child brides and media intervention cause severe pains in Turkey. Reactions to those issues reflect on contemporary art production and visual culture. In order to be a democratic society, these topics should be discussed. However, in art classes critical approaches shouldn't be implicated with theoretical template. Instead, it is essential to use more practical approaches.

5) Intercultural interactions: In Turkey, partnerships, which are formed by the help of Erasmus, Erasmus Plus and Mevlana Programs, established between different universities necessitate intercultural interaction. For this reason, we should develop course drafts that focus on interculturality and multiculturalism. 


\section{References}

Antmen, A. (2010). 20. Yüzyıl Sanatında Akımlar [Movements in 20th Century Art]. Üçüncü Bask1, İstanbul: Sel Yayıncılık.

Anderson, T. (2003). Art education for life, Journal of Art and Design Education, 22(1), 5866.

Aykut, A. (2012). Sanat Eğitiminde Estetik [Aesthetics in Art Education], İstanbul: Hayalperest Yayınevi.

Beyhan, C. (2011). Teknoloji ve sanat: Teknolojik gelişmelerin plastik sanatlar üzerindeki etkileri [Technology and art: the impact of technological developments on the plastic arts]. 1. International Art Symposium, (pp.131-140), (17 October 2011) Gazi Universty, Ankara.

Clark, R. (1996). Art Education: Issues in Postmodernist Pedagogy, Reston, VA: National Art Education Association.

Dewey, J. (2005). Art as Experience. New York: Perigee Book.

Duncum, P. (2001). The theories and practices of visual culture in art education, Arts Education Policy Review, 105 (2) 19-25.

Duncum, P. (2002). Theorizing everyday aesthetic experience with contemporary visual culture, Visual Arts Research, 28 (2), 4-15.

Duncum, P. (2008). Thinking critically about critical thinking: Towards a post-critical' dialogic pedagogy for popular visual culture, International Journal of Education though Art, 4 (3), 247. 
Eker, M. ve Seylan, A. (2005). Çağdas sanat eğitiminde sanatsal ve pedagojik postmodern montajlar [Artistic and pedagogical postmodern assemblies in the contemporary art education]. Eurasian Journal of Educational Research, 19, 164-178.

Eker, M., Baltaci, H. ve Sengir, S.(2010). Görsel Kültür Eğitimi: Sistematik sanat egitiminden stratejik sanat eğitimine geçiş [Visual Culture Education: the transition from the systematic art education to the strategic art education]. 2. Ulusal Güzel Sanatlar Eğitimi Sempozyumu Bildiri Kitabı, (pp. 153-160), (8-10 Nisan 2010), Çanakkale: Onsekiz Mart University.

Eurydice (2009). Arts and cultural education at school in Europe. Retrieved from http://www.eurydice.org

Freedman, K. (1997). Visual art/virtual art: teaching technology for meaning, Art Education, $50(4), 6-12$.

Freedman, K. (2003). Teaching visual culture: Curriculum, aesthetics, and the social life of art. New York: Teacher College Press.

Garoian, C.R.(2013). The Prosthetic Pedagogy of Art: Embodied Research and Practice, Albany, New York: Sunny Press.

Gaudelius, Y., Speirs, P.(2002). Contemporary Issues in art Education, New Jersey: Prentice Hall.

Giroux, H. (2000). Impure acts: The practical politics of cultural studies, New York: Routledge.

Gude, O. (2007). Postmodern Principles: In Search of a 21st century art education, Art Education, 57 (1), 6-14. 
Gude, O. (2007). Principles of possibility: Considerations for a 21st century art and culture curriculum, Art Education, 60 (1), 6-15.

Keifer-Boyd, K., Amburgy, P., \& Knight, W. (2003). Three approaches to teaching visual culture in K-12 school contexts. Art Education, 46 (2), 44-51.

Keifer-Boyd, K. \& Maitland-Gholson (2007). Engaging Visual Culture, Massachusetts: Davis Publications.

Keifer-Boyd, K. (2009). CyberNet activist art pedagogy. In A. Arnold, A. Kuo, E. Delacruz \& M. Parsons (Eds.), G.L.O.B.A.L.I.Z.A.T.I.O.N, Art, and Education (pp. 126-134). Reston, VA: The National Art Education Association.

Keifer-Boyd, K. (2010). Masquerading the immateriality of materiality. In R. W. Sweeny (Ed.), Inter/sections/Inter/actions: Art Education in a Digital Visual Culture (pp. 170181). Reston, VA: The National Art Education Association.

Mc Laren, P. (2003). Critical pedagogy: A look at the major concepts, In A. Doder, \& D. Torres (Ed) The critical Pedagogy Reader, (pp. 69-96), New York: Routledge Falmer.

Mirzoeff, N. (1998). The Visual Culture Reader, New York: Routledge.

Musneckiene, E. (2012). Trends in art education in the international context, In H. Sederholm (Ed), Art Beat (pp.141-171). Helsinki, Finland: Aalto University Publication.

Soğancı, Ö. (2011). Türkiye'de görsel kültür: Uluslararası öğrenci kitlesine yönelik bir uygulama örneği [Visual culture in Turkey: an application example for the international students]. 1. Sanat ve Tasarım Eğitimi Sempozyumu Bildiri Kitabı (pp. 72-76) (27-29 Nisan 2011) Ankara: Baskent Universty. 
Stokrocki, M. (2006). Searching for meaning: visual culture from an anthropological perspective. Art Education, 59 (1), 46-52.

Sturken, M., \& Cartwright. L. (2009). Practices of looking: An introduction to visual culture, New York: Oxford University Press.

Tavin, K. (2000). Teaching in and through visual culture. Journal of Multi-cultural and Cross-cultural Research in Art Education, 18, 37-40.

Tavin, K. (2002). Engaging advertisements: Looking for meaning in and through art education. Visual Arts Research, 28 (2), 38-47.

Tavin, K. (2003). A critical pedagogy of visual culture as art education: Toward a performative inter/textual practice. Unpublished Doctoral Dissertation. The Pennylvania State University, USA.

Tavin, K. (2004). If you see something, say something: visual events at the visual culture gathering. Visual Arts Research, 32 (2), 2-6.

Taylor, P. (2009). Madonna and hypertext: Liberatory learning in art education, Studies in Art Education, 41 (4), 347-389.

Tillander, M. (2011). Creativity, technology, art and pedagogical practices, Art Education, 64 (1), 40-46.

Varto, J. (2012). Contemporary art and art education: strategies and dead ends, In H. Sederholm (Ed), Art Beat (pp.67-84). Helsinki, Finland: Aalto University Publication.

Yılmaz, S. (2010). Görsel sanatlar eğitiminde çağdas yaklaşımlar [Contemporary trends in visual arts education]. 2. Ulusal Güzel Sanatlar Eğitimi Sempozyumu Bildiri Kitabı (pp. 183-186) (8-10 Nisan 2010), Çanakkale: Onsekiz Mart University. 